\title{
Introduktion: Journalistik i en industri
}

\section{AF ASKE KAMMER}

Når talen falder på forholdet mellem journalistik som en publicistisk praksis og en forretning, har det været en ofte hørt erklæring i redaktionslokalerne, at "vi laver ikke avis for at tjene penge - vi tjener penge for at kunne lave avis". Den journalistiske proces og dens produkt fremhæves altså som værdifulde i sig selv, mens den kommercielle dimension først og fremmest forstås som et middel til at nå et mål. Som en nødvendighed for at kunne opfylde journalistikkens ædle ambition om at tjene offentligheden. Af samme grund har der traditionelt været vandtætte skotter mellem redaktioner og annonceafdelinger, så journalisterne med deres særlige, faglige indsigt og professionelle rutiner ikke blev (negativt) påvirket af økonomiske hensyn (se Willig, 2010).

Det er imidlertid en tilstand, som over den seneste årrække har været under forandring. En række forskellige, men dog forbundne udviklinger har nemlig udfordret traditioner og medvirket til, at journalistikkens forretningsmæssige vilkår er kommet mere i fokus. Det er et økonomisk fokus, som går videre end det politisk-økonomiske paradigmes opmærksomhed på økonomi og ejerskab som afgørende faktorer i forhold til nyhedsmediernes indhold (se Schudson, 2005, for en oversigt). Det har nemlig nærmere at gøre med, hvordan journalistikken helt fundamentalt kan finansieres, end hvordan pengestrømmene i denne finansiering påvirker journalistikken ideologisk og politisk.

En udvikling, som har været af højeste vigtighed for refokuseringen blandt både praktikere og akademikere, er de teknologiske ændringer gennem de seneste omtrent 20 år. Internettet blev allemandseje med publiceringen af World Wide Web-applikationen og introduktionen af grafiske brugergrænseflader (brow- 
sere) i starten af 1990'erne (Castells, 2001), og det er i dag svært at overvurdere den digitale teknologis betydning for eksempelvis mødet mellem nyhedsorganisationerne og deres kunder. Over de seneste 10-15 år er der således sket en markant udvikling i retning af, at stadig større dele af befolkningens nyhedsforbrug foregår på digitale, internetbaserede nyhedskilder: Hvor det i 2001 var 41 procent af den danske befolkning, som brugte internettet til at tilgå nyheder (IT og Forskningsministeriet, 2001), var tallet i 2013 steget til 81 procent (Nielsen \& Schrøder, 2013). Tilsvarende er andelen, som læser en trykt avis, nede på 47 procent (Nielsen \& Schrøder, 2013). Fremskrives de aldersmæssige variationer i brugen af forskellige nyhedsmedier, forekommer en yderligere, fremtidig radikalisering af disse udviklinger at være et særdeles realistisk scenario.

Dette skifte udfordrer nyhedsorganisationerne på deres indtjening, for de stadigt faldende oplags- og læsertal på tværs af aviserne har ikke kun medført et økonomisk pres på grund af de faldende indtægter fra abonnements- eller løssalg. Ændringerne i brugsmønstrene har også stor økonomisk betydning, fordi annonceindtægterne online generelt er betydeligt mindre end på tryk; ifølge Jones og Salter (2011:37) er en avislæser i Storbritannien eksempelvis anslået til årligt at være $18 £$ værd i annonceindtægter, mens en netavislæser kun er 1,2 $£$ værd. Set i kombination med, at brugerbetaling for onlinenyheder endnu har til gode for alvor at slå igennem, udgør den digitale bevægelse en helt konkret udfordring for journalistikkens indtjeningspotentiale.

De udfordringer, denne økonomiske situation i sig selv udgør, er samtidig blevet intensiveret af den globale finanskrise, som siden 2008 har om ikke eroderet så i hvert fald svækket det økonomiske fundament både hos medieorganisationerne selv og hos annoncørerne, som har haft mindre budgetter at gøre godt med.

Og så er annoncørerne i vid udstrækning rykket til andre medieaktører, hvor de oplever at få mere for pengene. Destinationen for dette ryk er først og fremmest Google og Facebook, som i 2011 stod for omtrent 63 procent af danskernes samlede brugte onlinetid (Danske Medier, 2012), og hvor annoncerne i højere grad end hos nyhedsorganisationerne kan rettes direkte til meget 
klart definerede målgrupper. Individuelle reklamer tilpasset konkrete søgeord og eksplicitte, individuelle interessetilkendegivelser rammer målgruppen renere end trykte annoncer til mange tusinde læsere. Kampen om opmærksomhed er således skærpet, og nyhedsorganisationerne kæmper ikke kun mod hinanden i det digitale samfund - de kæmper mod hinanden, internationale nyhedsorganisationer, fritstående nyhedsmedier, aggregerende nyhedssider, sociale medier, blogs, underholdningssider og alt muligt andet. Og selvom netaviserne generelt ligger højt på listen over de mest velbesøgte netsteder, vil situationen for de etablerede nyhedsorganisationer sandsynligvis aldrig igen blive som i de gode gamle dage...

Udviklinger som disse har medført et øget fokus på, at der er en økonomisk side af nyhedsproduktionen, og at journalistikken indgår som en del af en større industri. I takt med at den traditionelle finansiering af nyhedsproduktion gennem to hovedkilder - annoncesalg og brugerbetaling (løssalg eller abonnement) - ikke længere genererer tilstrækkelige indtægter, er overvejelser omkring og hensyn til finansiel stabilitet til stede, også inde i redaktionslokalerne. Den journalistiske udvælgelse af nyheder præges således i stigende grad af kommercielle hensyn (se eksempelvis Kammer, 2013), og emneområder, som kan være økonomisk lukrative - eksempelvis vægttab og motionsløb opprioriteres på trods af en begrænset, publicistisk relevans (se Barland, 2012). Der er således ikke kun tale om en akademisk, teoretisk diskussion, men om en del af den journalistiske hverdag.

Den journalistik, som er blevet udført inden for rammerne af de etablerede medieorganisationer, har altid i en vis udstrækning været underlagt de økonomiske vilkår i nyhedsindustrien. Men i den situation, som medierne befinder sig i nu, er det tydeligere end før, at nyhedsproduktionen netop er en del af en industri.

Der er fem artikler i dette temanummer, som forholder sig til dette forhold, og som gør det med ganske forskellige tilgange. Nogle af dem beskæftiger sig med udviklinger og forretningsmæssige tilpasninger, som kun lige er begyndt, og hvor fremtiden endnu er ukendt, mens andre har en solid, historisk forandring og beskriver nogle af de store linjer i nyhedsindustrien. De fleste af dem forholder sig til udviklinger inden for de skandina- 
viske lande, som falder inden for den demokratisk-korporative mediemodel (Hallin \& Mancini, 2004), mens en enkelt har et tværeuropæisk fokus. Fælles for alle fem temaartikler er imidlertid, at de forholder sig empirisk til genstandsfeltet og tilbyder indblik i, hvordan nyhedsorganisationer forholder sig til forretningsmæssige udviklinger og en økonomisk omskiftelig omverden, og hvordan markedet for nyheder fungerer.

Efter disse fem artikler følger en række artikler uden for tema, som er redigeret og introduceres af Michael Bruun Andersen.

I den første temaartikel analyserer Ohlsson med et svensk fokus de seneste 50 års institutionelle udviklinger inden for én særlig form for aviser, nemlig dem med fondsejerskab. På baggrund af mødereferater og andre organisationsdokumenter identificerer han fire overordnede udviklingslinjer for denne type aviser, som hver især er med til at opridse de strukturelle ændringer, der har fundet sted over det halve århundrede. Den følgende artikel befinder sig ligeledes på et makroniveau, idet Bakker her giver en oversigt over 10 års op- og nedture for gratisaviserne i Europa og argumenterer for, at de nationale markeder måske kun kan opretholde livsbetingelserne for én gratisavis hver. Artiklen beskæftiger sig dermed med et fænomen, som er særligt interessant i en dansk sammenhæng, hvor "gratisaviskrigen" op gennem 2000'erne udgør et vigtigt, men endnu relativt ubeskrevet kapitel i nyere dansk pressehistorie (se dog Kammer, 2009; Minke, 2008).

De følgende to artikler rykker begge tættere på redaktionslokalerne og beskæftiger sig med, hvordan der reageres på de forretningsmæssige udfordringer, som forskellige organisationer på nyhedsmarkedet står over for. Holand beskriver således, hvordan der i små lokalsamfund i Nordnorge forekommer to tilsyneladende modsatrettede, men dog simultane udviklinger, nemlig mod øget mediekoncentration og oprettelsen af nye, uafhængige aviser med ekstremt lokalt fokus. Selvom den geografiske dimension i artiklen er yderst fokuseret, trækker udviklingen paralleller til den udvikling imod lokalisering af journalistikken, som også ses på flere andre markeder. I temaets fjerde artikel giver Barland et indblik i den forretningsmæssige frontlinje, hvor den enkelte journalists arbejde konkret påvirkes af nye initiativer til at generere indtægter. Her gennemgås konkrete cases af, hvordan jour- 
nalistikken bruges til at stimulere alternative indtjeningsmuligheder i form af eksempelvis pengeudlån.

Endelig tager Wadbring med temaets sidste artikel fat på et begreb, der implicit har ligget som en understrøm i de fire foregående artikler og den generelle, akademiske og offentlige diskussion om journalistik som en del af en forretning, nemlig kommercialisering. Ved at syntetisere spørgeskemaundersøgelser fra tre årtier kortlægger hun svenske journalisters syn på kommercialiseringen og dens konsekvenser.

God læselyst.

\section{REFERENCER}

Barland, Jens (2012). Journalistikk for markedet. Oslo: Universitetet i Oslo.

Castells, Manuel (2001). The Internet Galaxy. Reflections on the Internet, Business, and Society. Oxford: Oxford University Press.

Danske Medier (2012). Danskernes brug af internettet 2012. København: Danske Medier.

Hallin, Daniel C., \& Mancini, Paolo (2004). Comparing Media Systems. Three Models of Media and Politics. Cambridge: Cambridge University Press.

IT og Forskningsministeriet (2001). Trends $i$ kvalitativ brug af Internettet. København: IT og Forskningsministeriet.

Jones, Janet, \& Salter, Lee (2011). Digital Journalism. London: Sage Publications.

Kammer, Aske (2009). Gratisaviserne som politisk ressource. København: Københavns Universitet.

Kammer, Aske (2013). The mediatization of journalism. MedieKultur, 54, pp. 141-158.

Minke, Kim (2008). Aviskrigen. Dagblade i overlevelseskamp. Valby: Borgen.

Nielsen, Rasmus Kleis \& Schrøder, Kim (2013). Danskernes brug af nyhedsmedier 2013. Roskilde: Center for Magt, Medier og Kommunikation, Roskilde Universitet.

Schudson, Michael (2005). Four Approaches to the Sociology of News. In: J. Curran \& M. Gurevitch (red.), Mass Media and Society (4th ed., pp. 172-197). London: Hodder Arnold.

Willig, Ida (2010). Constructing the audience: a study of segmentation in 
the Danish press. Northern Lights. Film and Media Studies Yearbook, 8, pp. 93-114.

ASKE KAMMER er adjunkt i digital journalistik ved Center for Journalistik, Syddansk Universitet.

kammer@journalism.sdu.dk 